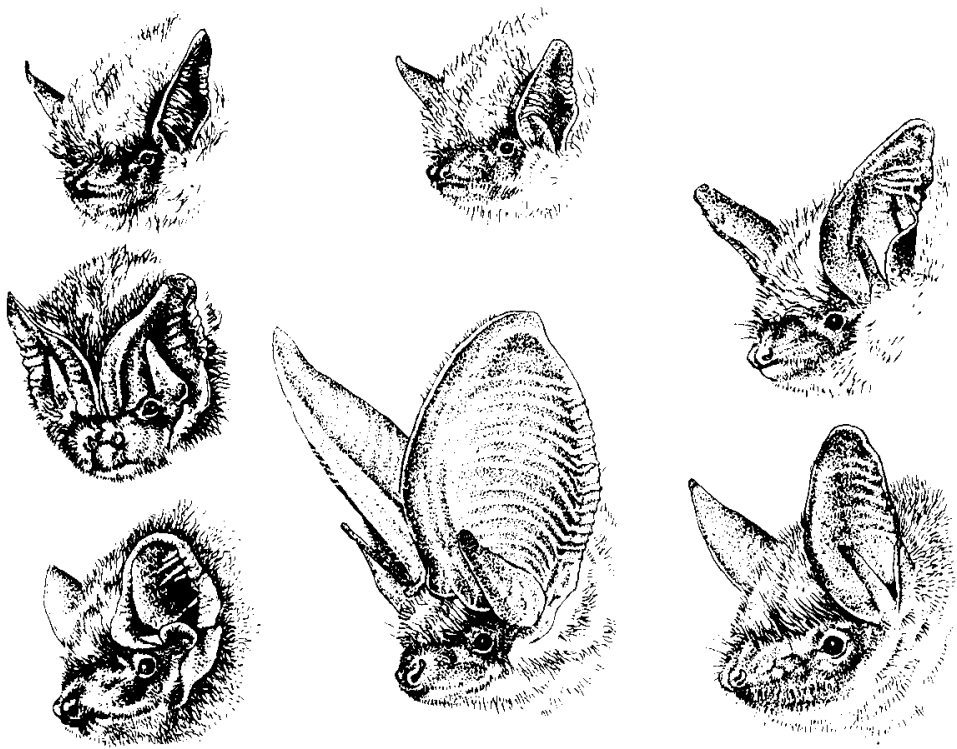

SEVEN RARE BRITISH BATS: left to right, top whiskered and Brandt's; middle barbastelle and Bechstein's; bottom Leisler's, grey long-eared and mouse-eared. A drawing by Priscilla Barrett, reproduced from the RSPCA Book of British Mammals, edited by C.L. Boyle, ffPS Vice-President, (Collins, £8.75), which will be reviewed in the next Oryx.

plants. This section deals purely with African and British examples. Three papers on introductions, all in Britain, explore this controversial problem in rather different ways, and there are seven papers on various aspects of protected areas for rare plants.

This conference clearly served a useful purpose in bringing together botanists from many countries to discuss conservation problems of mutual concern. Perhaps inevitably the published proceedings are an uneasy mixture of pure science and applied conservation. It would be impossible to discuss all the 42 papers in a brief review, but a few caught my interest: from the Survey and Assessment section, those of Nilsson.on threatened Swedish plants, and Crompton on rare plants in eastern England, and the panel discussion on the too often neglected topic of conservation of lower plants is very important. In the discussions of rarity as a concept, John Harper's paper is predictably thought-provoking, while Margaret Bradshaw gives a graphic account of one of the few examples, that of Teesdale, of long-term monitoring of rare plants. Several of the ecological studies are very valuable, and the problem of introduction is well aired. Perhaps the suggestions of Ranwell that introductions of coastal plants, including aliens, could be increased, deserve further discussion.

All botanists concerned with the future of wild plants should read this book, and if it encourages some to take positive steps to study, understand, and eventually conserve some rare species it will achieve its purpose. All royalties go to ffPS plant projects.

S.R.J. WOODELL

\title{
International Organisations and the Conservation of Nature, by Robert Boardman. Macmillan, $£ 15$.
}

The history of institutions can only be brought to life if it is written in terms of the personalities that operated them. This is inevitably largely a history of IUCN. But although Professor Boardman mentions some individuals from time to time - Paul Sarasin, for instance, Julian Huxley, Jean-Paul Harroy, Peter Scott - he in no way discusses IUCN in terms of the succession of able presidents and secretaries who have run it. An analysis of the impact of Harold Coolidge, who unexpectedly became president when Ed Graham died, would have made fascinating reading. An indication 
of and the degree to which the last twenty years of both IUCN and WWF have been influenced by Sir Peter Scott would show how very much we are all in the debt of that outstanding conservation virtuoso. But I must not blame the author for writing the book I would have like him to instead of the one his material has enabled him to. For this is a classic instance of a historian's documentary approach - compare John Sheail on the British conservation movement. When one knows how little of most meetings gets into the written record, it is always astonishing that historians are able to learn what really happened from written records. But, supplemented, one must suppose, by a good deal of hearsay and discussion with still living actors, here is an excellent account of how first ICBP, then IUCN and finally WWF came about, and a reasonably detached view of their achievements: CITES, the African Convention and the Polar Bear Convention are among the highlights. But what one cannot get from the documents, or only with great difficulty, is how all these institutional achievements worked out on the ground. How many acres of habitat were saved from devastation? How many species or even populations are still in being that would not have been if ICBP, IUCN and WWF had never existed? These are the questions one would like the author to turn to next.

RICHARD FITTER

\section{The Oxford Companion to Animal Behaviour, edited by David McFarland. Oxford UP, £17.50.}

This addition to the Oxford Companions is not, as first inspection might lead one to believe, a dictionary or encyclopaedia, but an introductory handbook to the subject of ethology and is intended as a work of reference for the general reader. It contains over 200 separate articles, written by a team of 70 specialists, on every aspect of the subject and the related disciplines of ecology, genetics, physiology and psychology necessary to give the layman the background of biological knowledge he needs to be able to understand this rapidly expanding subject. Liberal cross-references supplement the information as do the references to original accounts listed in the bibliography.

Particularly helpful for the general reader is an extended article on the history of the study of animal behaviour from the earliest times to the present, and also accounts of the work of pioneers such as Charles Darwin, Konrad Lorenz, Niko Tinbergen and Karl von Frisch. Splendid line illustrations mainly by Tim Halliday complement the text admirably. An index to English names of animals and another to scientific names enable details of investigations into particular species to be found easily.

JOHN CLEGG

\section{Australia's Threatened Plants}

Rare or Threatened Australian Plants, by John Leigh, John Briggs, and William Hartley, published by the Australian National Parks and Wildlife Services, is a revised and substantially enlarged edition of a 1979 paper Plants at Risk in Australia. It includes lists of threatened plants with maps for each Australian state, and of endemic species on Australian islands in the Pacific, Indian and Antarctic Oceans, such as Lord Howe, Norfolk and Macquarie, with notes on their conservation status. The total number of plants to which the title applies is 1206 . Christmas Island in the Indian Ocean has 21 endemic species, some of which are still threatened by the phosphate mining there. (PO Box 636, Canberra City, ACT 2601.)

\section{Making Grassland}

Creating Attractive Grassland using Native Plant Species is the self-explanatory title of a booklet by Terry Wells, Shirley Bell and Alan Frost, obtainable from the Nature Conservancy Council. It tells how to collect seeds (hand gathering, from hay bales, mechanical cutting), how to clean store and label them, how to germinate and propagate them, and how to make up suitable mixtures. $£ 3.20$. 